\title{
Vincent S. Leung \\ Chuci and the Politics of Space under the Qin and Han Empires
}

To create a new state is to create a new space. It entails the construction of a new environment for all things under its dominion. ${ }^{1}$ This is true for any type of state, but it is particularly germane when we consider the formation of an empire. Empires are a type of political structure that is defined, most importantly, by their drive towards territorial expansion. As Charles Maier, in his study of empires in world history, noted: "An empire in the classic sense is usually believed, first, to expand its control by conquest or coercion, and, second, to control the political loyalty of the territories it subjugates." ${ }^{2}$ In other words, empires are constituted through relations of domination by one group over another in a territory that is not originally their own. To create an empire, therefore, is to create an expansive political space, one that extends itself without compromising its political integrity. In this sense, all empires implicate and subsist on a politics of space; it is a form of political authority that is realized and maintained through a reconfiguration of spatial relations.

In this paper, I will explore this politics of space under the rise of the Qin and the Han empires (221 BCE-220 CE) in early China. What spatial claims did these early empires make, and what historical responses were there from the political elite? The text that I will be using as a point of entry for this historical contention over spatial relations is the Chuci 楚辭 (Chu Lyrics). This ancient collection of poetry is a somewhat unlikely choice. The Chuci does contain a few

Note: The author would like to acknowledge and thank the financial support from Lingnan University for the research and writing of this chapter through its Direct Grant program (DR19A8) from 2019-2020.

1 On the "spatiality of political life," see Adam T. Smith, The Political Landscape: Constellations of Authority in Early Complex Polities (Berkeley: University of California Press, 2003), esp. 12.

2 Charles S. Maier, Among Empires: American Ascendancy and Its Predecessors (Cambridge, MA: Harvard University Press, 2006), 24-25. There are many competing definitions of empires, but they all invariably emphasize this spatial dimension. For instance, Michael Hardt and Antonio Negri wrote, "First and foremost, then, the concept of Empire posits a regime that effectively encompasses the spatial totality, or really that rules over the entire 'civilized' world. No territorial boundaries limit its reign.” Empire (Cambridge, Mass.: Harvard University Press, 2000), xiv; and in Michael Doyle's Empires (Ithaca, N.Y.: Cornell University Press, 1986), 19: "Empires are relationships of political control imposed by some political societies over the effective sovereignty of other political societies.” 
Han-period pieces, but it is more typically read in the context of its association with the Chu 楚 kingdom of the preceding Warring States era (ca. 475-221 BCE). Once a powerful southern kingdom at the central Yangzi valley, the Chu finally fell to the Qin armies after decades of resistance in the year 223 BCE. ${ }^{3}$ Memory of the kingdom, however, persisted. In the next few centuries, under the early empires, there would be an extraordinary amount of memorial investment in the bygone kingdom of $\mathrm{Chu}$. Lore about this once-influential southern kingdom proliferated, and literary pieces associated with it enjoyed wide currency. ${ }^{4}$ Towards the end of the Han empire in the second century CE, this very active afterlife of the Chu kingdom would culminate in the compilation of the Chuci zhangju 楚辭章句 (Chapter and Verse Commentary to the Lyrics of Chu) by Wang Yi 王逸 (fl. 130s), an anthology of poems attributed to poets from both the Chu kingdom and the Han dynasty. This compilation had a defining effect for the Chu lyrics tradition; its nearly sixty poems established its basic repertoire, and Wang Yi's commentaries laid the first stone of the exegetical tradition of Chu lyrics that would develop in the centuries to come.

There are therefore (at least) two historical contexts for a reading of the Chuci poems. One can read them against the history and culture of the Chu kingdom, the purported origin for this distinctive style of poetry, or one can read them in the context of the early imperial era, a time when they enjoyed great popularity among the political elite who took to ensuring their preservation. In this paper, I will opt to do the latter. Reading the Chuci pieces alongside other early imperial texts, especially the court literature of the Qin and Han empires, will tell us a great deal about the contentious politics of space of this period. The abiding interest in the Chuci poems and their lore was no historical accident but an artifact of the spatial politics of the early imperial period. They were purposefully mobilized, as a well-wrought language for articulating displacement, in response to the spatial claims of the Qin-Han empires. Through their analysis, we can question how the aesthetic composition of space may provide opportunities for contestation against the state's possessive representation of its landscape.

3 For a summary of the history of Chu, see Barry B. Blakeley, 'The Geography of Chu', in Defining Chu: Image and Reality in Ancient China, ed. by Constance A. Cook and John S. Major (Honolulu: University of Hawai'i Press, 1999), 9-20.

4 For a great survey of the literary representations of the Chu kingdom in Han dynasty texts, see Gopal Sukhu, "Monkeys, Shamans, Emperors, and Poets: The Chuci and Images of Chu during the Han Dynasty," in Defining Chu: Image and Reality in Ancient China, ed. Constance A. Cook and John S. Major (Honolulu: University of Hawaii Press, 2004), 145-166; and Lu Kanru 陸㑆如, “Han ren lun Chuci” 漢人論楚辭, in Lu Kanru gudian wenxue lunwen ji 陸㑆如古 典文學論文集 (Shanghai: Shanghai guji, 1987), 371-401. 
The argument will unfold over three sections. In the first section, I will elaborate on what I have just briefly discussed, namely the history of the Chu lyrics under the early empires, especially the Chuci zhangju from the late Han empire. In the second section, I will offer a reading of some of the Chuci poems and discuss what I consider to be one of their salient features, namely a poetics of displacement. Then, in the third and last section, I will situate these Chuci poems in the context of other early imperial court writings and discuss how their juxtaposition would point us towards a history of spatial politics under the rise of empires in early China. The Chuci poems did not just happen to exist - and flourish - under the early empires but were a literary fallout of the spatial contention of the Qin-Han empires.

\section{Chuci zhangju and Chu Lyrics under the early empires}

The origin and early history of the Chu lyrics tradition is a minor puzzle in the study of early Chinese literature and history. None of the poems in the Chu lyrics repertoire can be confidently attested from the time of the Chu kingdom, and even the term “Chuci” 楚辭 - “Chu lyrics” or “songs of the Chu” - did not appear in the extant corpus until the first century BCE in the hands of early Han politicians. ${ }^{5}$ Speculations abound about the pre-imperial history of this poetic tradition, and inevitably, the discussion always returns to the first compilation and the oldest commentaries of the "Chu lyrics" in the aforementioned Chuci zhangju by Wang Yi, a collator (jiaoshu lang 校書郎) at the imperial library during the reign of Emperor An of the Han dynasty (Han Andi 漢安帝, r. 94-125). ${ }^{6}$ The Chuci zhangju is divided into seventeen books, each with a

5 One of its first appearances of this term is in the Shiji 史記 by Sima Qian 司馬遷 (d. 86 BCE) (Beijing: Zhonghua, 1959), 122.3143. See You Guo'en 游國恩, “Chuci gailun” 楚辭概論, in You Guo'en Chuci lunzhu ji 游國恩楚辭論著集, 4 vols (Beijing: Zhonghua shuju, 2008), iii, 7-9. For a discussion of the probable pre-imperial origins of the Chu lyrics tradition, see You Guo'en游 國恩, “Chuci de qiuyuan” 楚辭的起源, in You Guo’en Chuci lunzhu ji 游國恩楚辭論著集, 4 vols (Beijing: Zhonghua shuju, 2008), iv, 114-26.

6 Wang Yi's official career as a collator at the imperial library, and subsequently as a palace attendant (daizhong 侍中), may have extended into the reign of Emperor Shun (Han Shundi 漢 順帝, r. 115-144 BCE). See Fan Ye 范瞱, Hou Hanshu 後漢書 (Beijing: Zhonghua, 1965), 80.2618, with the commentary by Jiang Tianshu 蔣天樞, “Hou Han shu 'Wang Yi zhuan' kaoshi” 後漢書 王逸傳考釋, in his Chuci lunwen ji 楚辭論文集 (Xi’an: Shaanxi renmin chubanshe, 1982), 
single or a cycle of poems appended with Wang Yi's commentaries; the nearly sixty poems in this compilation, as noted above, would come to define the repertoire of the Chu lyrics tradition, and all later editions of the Chuci would be based on this earliest collection. ${ }^{7}$ This is the urtext of the Chu lyrics tradition.

Between the prefaces and interlinear glosses, Wang Yi offers in the Chuci zhangju not just explications of the individual poems but also an interpretive framework for the history of the Chu lyrics tradition. Like all commentarial texts, Wang Yi's exegesis is descriptive in gesture and prescriptive in substance. His explanation for how a poem should be read is really an argument for how it ought to be read. His basic commentarial strategy in the Chuci zhangju is to situate each of the Chu lyrics in the circumstances of their compositions. Put differently, for Wang Yi, the key to understanding a Chu lyric lies, in large part, in knowing how its author came to compose it. Accordingly, each of the seventeen books in the Chuci zhangju has a clear attribution, beginning with Chu writers from the late Warring States to the Han dynasty poets of his own time. The Chuci zhangju, in this sense, is more than just an anthology but also an history of the tradition of Chu lyrics through a selective compilation and explication of the works of successive poets over almost four centuries.

In Wang Yi's history of the Chu lyrics tradition, this poetic language originated in the southern kingdom of Chu. It was exemplified in the works by $\mathrm{Qu}$ Yuan 屈原 (ca. 340-278 BCE), a wrongfully disgraced minister of the kingdom, and to a lesser degree his younger contemporary Song Yu 宋玉 (fl. early third century BCE). Of the seventeen books in the Chuci zhangju, eight were attributed to the authorship of Qu Yuan. Two were attributed to Song Yu. Wang Yi did express some doubts regarding the authorship of the poem “Da zhao" 大招 (“The Great Summons"); even though he attributed it to Qu Yuan, he noted that it may also have been written by another Chu poet named Jing Cuo 景瑳 about whom we know nothing else. ${ }^{8}$ As for the remaining seven books, they were attributed to various Han dynasty writers, including the "Jiu si” 九思 ("Nine Longings”) by Wang

195-212. See also Wang Qizhou 王齊洲, “Wang Yi he Chuci zhangju” 王逸和《楚辭章句》, Wenxue yichan 文學遺產 2 (1995), 23-30.

7 For the textual history of the Chuci, including the history of the different editions, see Kominami Ichirō 小南一郎, Soji to sono chūshakushatachi 楚辭とその注釈者たち (Kyoto: Hōyū shoten, 2003); and David Hawkes, “Ch'u tz'u," in Early Chinese Texts: A Bibliographical Guide, ed. Michael Loewe (Berkeley: The Society for the Study of Early China and the Institute of East Asian Studies, University of California, 1993), 48-55.

8 Hong Xingzu 洪興祖, ed., Chuci buzhu 楚辭補注 (Bejing: Zhonghua, 1983), 216. All references to the Chuci are based on this edition of the Chuci zhangju with additional annotations by Hong Xingzu (1090-1155). Unless otherwise noted, all translations from the Chuci are adapted from Hawkes, The Songs of the South, with some minor modifications. 
Yi himself. For each book, he also included a preface on the historical circumstances of their composition. Some of these prefaces are more elaborate than the others; the ones for the pieces attributed to $\mathrm{Qu}$ Yuan are generally more detailed. Together, they gave us a picture of a virtuous courtier who, confounded by the moral perversions of the world, decided to drown himself as the only possible means of escape with his integrity intact. ${ }^{9}$ The tradition continued to flourish after the death of $\mathrm{Qu}$ Yuan in the works of the later Chu poets. Han writers from the beginning of the empire to his own time, including Wang Yi himself, continued to write "Chu lyrics," even though the Chu kingdom had perished for centuries.

This is the basic outline of the history of the Chu lyrics tradition that emerged from a reading of the Chuci zhangju. It is certainly a plausible account, but one interesting problem quickly emerges if we started to read through the Warring States corpus for confirmation. These Chu poets Qu Yuan and Song Yu, as well as their lyrics collected in the Chuci zhangju, did not leave behind a single trace in the writings from their own time, say, the long third century BCE. The absence of evidence does not necessarily disprove the veracity of Wang Yi's account, of course, but nevertheless, it stands in contrast to the historical importance that Wang Yi had accorded to these Chu poets and their works. For the first traces of this narrative about the history of the Chu lyrics tradition, one would have to wait until after the destruction of the kingdom in 223 BCE. It was in the first decades of the Han empire, in the early second century BCE, that we have certain references to the poet Qu Yuan. One of his earliest appearances was in the “Diao Qu Yuan fu” 局屈原賦 (“A Lament for Qu Yuan”) by the early Han politician Jia Yi 賈誼 (200-168 BCE). With a prosody nearly identical to that of the pieces in the Chuci, this rhapsody ("fu" 賦) also suggests a familiarity with the biography of Qu Yuan consistent with the one given in Wang Yi's Chuci zhangju. ${ }^{10}$ And interestingly, from this point onwards, we would find regular references to the Chu lyrics tradition and the various historical personalities associated with it across a wide range of texts for the rest of the Han empire, in contrast to their stark absence in the late Warring States corpus.

9 Hong Xingzu, Chuci buzhu, 1-2, 55, 85, 120-121. For this notion of the "invulnerability of integrity" in the representations of Qu Yuan, see the excellent discussion in Michael D. K. Ing, The Vulnerability of Integrity in Early Confucian Thought (New York, NY: Oxford University Press, 2017).

10 Sima Qian, Shiji, 84:2492-2495. I borrow the translation of this song title from David R. Knechtges and Taiping Chang, eds., Ancient and Early Medieval Chinese Literature: A Reference Guide, Part One (Leiden: Brill, 2010), 126. 
In particular, there seemed to have been a surge of interest during the reign of Emperor Wu (Han Wudi 漢武帝, r. 141-87 BCE). For instance, a certain Zhu Maichen 朱買臣 (fl. 120-110 BCE) gained favor with Emperor Wu for his expertise of "Chu lyrics," according to an anecdote in the Shiji, where we also have the earliest attested use of the term "Chuci." the Prince of Huainan Liu An 劉安 (179-122 BCE) to write a commentary on the “Li sao” 離騷 (“Li sao zhuan” 離騷傳 [“On Encountering Trouble”]), a poem attributed to $\mathrm{Qu}$ Yuan that will come to be the very centerpiece of the Chu lyrics tradition. ${ }^{12}$ Around the same time, Sima Qian, the Senior Archivist at Emperor Wu's court, compiled a biography of Qu Yuan as part of his Shiji. In addition to the details of Qu Yuan's career, this earliest biography of his also cites one poem (i.e. "Huai sha” [“Embracing Sand”] 懷沙) in full and mentions a few others by name (i.e. “Li sao” 離騷, “Tian wen” 天問 [“Heavenly Questions”], “Zhao hun” 招魂 [“Summons of the Soul”], and “Ai Ying” 哀郢 [“A Lament for Ying”]), all of which will be collected in the Chuci zhangju two centuries later. ${ }^{13}$

References to the Chu lyrics tradition continued to appear after the time of Emperor Wu's reign. Liu Xiang 劉向 (79-8 BCE) and his son Liu Xin 劉歆 (46 BCE-23 CE) included the poetic corpus of Qu Yuan and Song Yu in their bibliography of the imperial library. ${ }^{14}$ By this time, anecdotes about Song Yu also started to appear for the first time in texts such as the Hanshi waizhuan 韓詩外傳 and Xinxu 新序 by the same Liu Xiang. ${ }^{15}$ Later on, Yang Xiong 楊雄 (53 BCE-18 CE) wrote the poem “Fan Li sao” 反離騷 (“Anti-“On Encountering Trouble"') which ruefully reflects on Qu Yuan's decision to commit suicide. ${ }^{16}$ The same poem "Li sao" also attracted the attention of the great historian Ban Gu 班固 (32-92) a few decades later. He wrote a preface for it, the "Li sao zan xu" 離騷贊序 (“A Preface to 'On Encountering Trouble””), that recounts the tragic

\footnotetext{
11 Sima Qian, Shiji, 122:3142.

12 Ban Gu, Hanshu 漢書 (Beijing: Zhonghua, 1962), 44.2145.

13 Sima Qian, Shiji, 84.2481-2491.

14 Yao Zhenzong 姚振宗, Qi lüe bie lu yi wen; Qi lüe yi wen七略別錄佚文; 七略佚文 (Shanghai: Shanghai guji chubanshe, 2008). Wang Yi also noted that Liu Xiang compiled an anthology of Chu poems, on the basis of which he compiled the Chuci zhangju. See Hong Xingzhu, Chuci buzhu, 1. I also found useful the recent discussion of the imperial bibliographical efforts in Michael Hunter, “The 'Yiwen Zhi' 藝文志 (Treatise on Arts and Letters) Bibliography in Its Own Context," Journal of the American Oriental Society, 138.4 (2018), 763-780.

15 See Li Longxian 李隆獻, “Wenxuan Song Yu 'Dui Chu wang wen' jianzheng ji xiangguan de liangge wenti” 《文選》宋玉「對楚王問」箋證及相關的兩個問題, Taida zhongwen xuebao 臺 大中文學報, 6 (June 1994): 171-208.
}

16 Ban Gu, Hanshu, 87A:3515-3521. 
circumstances of Qu Yuan's life. ${ }^{17}$ And of course, in the last century of the Han empire, we have the first compilation and exegesis of Chu lyrics, namely Wang Yi's Chuci zhangju. It includes all the pieces that were already noted by these earlier Han writers as well as pieces that have never been mentioned before in our extant corpus. It also expands on the biography of Qu Yuan and draws a closer connection between the tragic circumstances of his life and the Chu lyric pieces attributed to him. One may say that the Chuci zhangju represents a culmination of the historical fabulation and intellectual investment in the Chu lyrics tradition, much of which centered on the figure Qu Yuan, over more than three centuries of the Han dynasty to Wang Yi's own time.

This is a rather curious history of a poetic tradition. All that we know about the Chu lyrics tradition came from sources that postdate the time of its eponymous kingdom. The absence of references to this purported tradition, and all its associated personalities and key pieces, in their own time stand in sharp contrast to the lavish attention that they received over the course of the Han empire. Accordingly, much of the modern scholarship on the Chuci has focused on the question of its origins. What were these songs from the southern region ${ }^{18}$ How were they performed and what functions did they serve? One popular answer is that these poems are remnants of a once flourishing shamanistic culture of the Chu kingdom, that they were "complete libretti" of certain shamanistic rituals. ${ }^{19}$ It is one of the few rare and widespread consensuses in the scholarship on the Chuci. ${ }^{20}$

17 Hong Xingzu, Chuci buzhu, 51.

18 The question of origins is a veritable obsession of the scholarship on the Chuci. To name just a few example: Zhou Weifeng 周蔁風, Chuci xue fasheng yanjiu 楚辭學發生研究 (Guilin: Guangxi shifan daxue chubanshe, 2008); Huang Bilian 黄碧璉, Qu Yuan yu Chu wenhua yanjiu 屈原與楚文化研究 (Taipei: Wenjin chubanshe, 1998); Zhao Kuifu 趙逵夫, Qu Yuan yu tade shidai 屈原與他的時代 (Beijing: Renmin wenxue chubanshe, 1996); and Zhao Hui 趙輝, Chuci wenhua Beijing yanjiu 楚辭文化背景研究 (Wuhan: Hubei jiaoyu chubanshe, 1995). There are, however, dissenting voices that suggested that the Chuci poems were all composed during the Han period: see He Tianxing 何天行, Chuci zuo yu Han dai kao 楚辭作於漢代考 (Shanghai: Zhonghua, 1948); and Hu Shi 胡適, “Du Chuci” 讀楚辭, in Hu Shi wencun 胡適文存 (Shanghai: Shanghai shudian, 1989), 2.139-148.

19 Arthur Waley, The Nine Songs: A Study of Shamanism in Ancient China (London: George Allen and Unwin, 1955), 5.

20 This reading of the Chuci poems as a shamanistic artifact has a long history and is widespread. See Fujino Iwatomo 藤野岩友, Fukei bungakuron 巫系文学論 (Tokyo: Daigaku Shobō, 1951); Hawkes, The Songs of the South, 42-51; and Ping-Leung Chan, "The Sacred and the Profane: A Study of the 'Chiu ko',” Tamkang Review XV, no. 1, 2, 3, 4 (1984-1985), 451-465; Burton Watson, Early Chinese Literature (New York: Columbia U.P., 1962), 242; K. C. Chang, Art, Myth, and Ritual: The Path to Political Authority in Ancient China (Cambridge: Harvard U.P., 1983), 47; 
Whatever the origins of the Chu lyrics tradition may be, what interests me here the most is its immense popularity during the Han empire. It was a veritable phenomenon among a very visible segment of the political elite. Among the thousands of things that the Han disinherited from the Warring States and earlier periods, the Chu lyrics were definitely not one of them. They became an object of appreciation, reflection and debates soon after founding of the empire. Scholars in the past decades have written about this surprising career of the Chu lyrics tradition during the Han empire, especially the political controversy and debates over the "Li sao" and the legend of Qu Yuan. ${ }^{21}$ However, these works are largely interested in what the history of the Chuci was during the Han empire but less the question of why there should be a history at all. What might have prompted this attention to the poetic form of a defunct kingdom? Why was it not simply forgotten and consigned to the dustbin of history? ${ }^{22}$ Let us now turn to the text of the Chuci poems themselves for an answer.

\footnotetext{
Martin Kern, "The Verses of Chu," in The Cambridge History of Chinese Literature, ed. Kang-I Sun Chang and Stephen Owen (Cambridge: Cambridge U.P., 2010), 82, 84. And of course, this is a much elaborated theme in the recent series of works by Gopal Sukhu: "Monkeys, Shamans, Emperors, and Poets," 164-165; The Shaman and the Heresiarch: A New Interpretation of the Li Sao, SUNY Series in Chinese Philosophy and Culture (Albany: State University of New York Press, 2012); and The Songs of Chu: An Ancient Anthology of Works by Qu Yuan and Others, Translations from the Asian Classics (New York: Columbia University Press, 2017).

21 The pioneer work by Lu Kanru 陸㑆如 called attention to the controversial history of the Chuci during the Han. See Lu Kanru, "Han ren lun Chuci," 371-401. For more recent work, see Michael Schimmelpfenning, "The Quest for a Classic: Wang Yi and the Exegetical Prehistory of His Commentary to the Songs of Chu,” Early China 29 (2004), 111-162; Shi Wenying 石文英, “Liang Han de 'Li sao' lunzeng ji qi yanxu” 兩漢的《離騷》論爭及其延續, Wen shi zhe, 2 (1988), 68-73; and Laurence Schneider, Madman of Ch'u: The Chinese Myth of Loyal and Dissent (Berkeley: University of California Press, 1980).

22 Scholars have suggested that the Chu origin of many members of the early Han political elite, including the ruling house of Liu 劉, may have accounted for this unusual popularity of the southern lyrics. It may very well have been a factor. See The Oxford Handbook of Classical Chinese Literature (1000 BCE-900 CE), ed. by Wiebke Denecke, Wai-Yee Li, and Xiaofei Tian (New York: Oxford University Press, 2017), 251; and You Guo’en 游國恩, “Qu Yuan” 屈原, in You Guo'en Chuci lunzhu ji 游國恩楚辭論著集, 4 vols (Beijing: Zhonghua shuju, 2008), iii, 539-548, which gives an exhaustive inventory of the Chu natives from amongst the first generation of the ruling elite of the Han empire.
} 


\section{Poetics of displacement in the Chuci}

Not surprising at all for an anthology of poetic pieces written over a few centuries, the Chuci is a diverse collection that is hardly susceptible to any simple generalization. There are, for instances, descriptions of cosmic journeys in the "Li sao" and “Yuan you” 遠遊 (“Far-off Journey"), failed encounters with deities in the "Jiu ge" ("Nine Songs") cycle, affectation of ignorance in the "Tian wen" ("Heavenly Questions”), expression of a scholar's frustration in the "Jiu zhang” 九章 (“Nine Pieces”), “Jiu bian” 九辯 (“Nine Changes”), and “Da zhao,” summoning of souls in the "Zhao hun" ("Summons of the Soul”), and the anecdotal narratives in "Yufu” 漁夫 (“The Fisherman”) and “Bu ju” 卜居 (“Divination”). And these are just the pieces that are attributed to the Chu poets. As for the other pieces attributed to the Han writers, they are mostly imitative, with permutations of the major themes and key vocabularies that resemble those in these supposedly earlier pieces.

Reading across the Chuci corpus, however, a few predominant themes do gradually emerge. ${ }^{23}$ One that is particularly pertinent to the argument of this chapter is their consistent interest in the depiction of landscape. In every Chuci poem, the narrative is always framed within a landscape or, at a minimum, situated within certain spatial relations. That is not to say that Chu lyrics are “landscape poetry" (shanshui shi 山水詩) like the ones by the later medieval poets such as Xie Lingyun 謝靈運 (385-443) that take landscape - or nature at large - as their primary object of poetic elaboration. ${ }^{24}$ Rather, in these Chu lyrics, there is always a construction of a landscape, or at the very least a reference to spatial markers, that serve as the narrative context for whatever subject matters the piece deals with. Sometimes, this landscape can be very minimal, as it is in the case of "Shan gui” 山鬼 ("Mountain Spirit”) from the "Jiu ge” cycle:

\footnotetext{
There seems to be someone in the fold of the mountain

In a coat of fig-leaves with a rabbit-floss girdle,

With eyes that hold laughter and a smile of pearly brightness:

'Lady, your allurements show that you desire me.'
}

若有人兮山之阿, 被薜荔兮帶女羅。既含睇兮又宜笑, 子慕予兮善窈宨。2

23 When referring to the "Chuci" or "Chu lyrics" in general, I am referring to the set of poems collected in the Wang Yi's Chuci zhangju.

24 See Wendy Swartz, "Naturalness in Xie Lingyun's Poetic Works," Harvard Journal of Asiatic Studies, 70.2 (2010), 355-86; and Francis A. Westbrook, "Landscape Transformation in the Poetry of Hsieh Ling-yün,” Journal of American Oriental Society, 100, no. 3 (July-August, 1980), 237-254. 25 Hong Xingzu, Chuci buzhu, 79. Once again, unless otherwise noted, all translations from the Chuci are adapted from David Hawkes, The Songs of the South. See note 8 above. 
Here, in the opening lines of the poem, we are immediately introduced to a landscape, however minimalistic it may be, i.e. "the fold of the mountain" (shan zhi $e$ 山之阿). The narrative is very clearly situated at a particular point in space. The rest of the poem details the failed encounter between the poet and the titular "mountain spirit" on this unnamed hill. It concludes with the forlorn poet standing alone in an unwelcoming, desolate landscape:

The thunder rumbles; rain darkens the sky:

The monkeys chatter; apes scream in the night:

The wind soughs sadly and the trees rustle.

I think of my lady and stand alone in sadness.

雷填填兮雨冥冥, 猨啾啾兮又夜鳴。風颯颯兮木蕭蕭, 思公子兮徒離憂。26

In “Xiang jun” 湘君 (“The Goddess of the Xiang”), another poem from the “Jiu ge” cycle, we are introduced to a similarly minimalistic landscape, centered around an island. It begins with the following stanza that immediately situates the narrative in space:

The goddess comes not, she holds back shyly.

Who keeps her delaying within the island in the center,

Lady of the lovely eyes and the winning smile?

Skimming the water in my cassia boat,

I bid the Yuan and Xiang still their waves

And the Great River make its stream flow softly.

君不行兮夷猶, 塞誰留兮中洲? 美要眇兮宜修, 沛吾乘兮桂舟。令沅湘兮無波, 使江水兮安流! ${ }^{27}$

The rest of the poem details the poet's treacherous attempt to navigate the waters to meet the goddess. And like the narratives in all the other "Jiu ge" poems, it ends in failure:

The stream runs fast through the stony shallows,

And my flying dragon wings swiftly above it.

The pain is more lasting if loving is faithless:

She broke her tryst; she told me she had not time.

石瀨兮淺淺, 飛龍兮翩翩。交不忠兮怨長, 期不信兮告余以不閒。28

Minimally delineated landscape such as an unnamed mountain or a lone island in these "Jiu ge" poems provide the spatial backdrop for their narratives of

26 Ibid., 81.

27 Ibid., 59-60.

28 Ibid., 63-64. 
failed encounters with deities. For a more expansive landscape, one can hardly find a better example than the "Li sao." Attributed to Qu Yuan, it begins with the poet's lamentation on the rampant corruptions in the world. In this world so thoroughly perverted, the poet can no longer find a place where his virtue is appreciated. And at that realization, he decided to take flight:

Suddenly I turned back and let my eyes wander.

I resolved to go and visit all the world's quarters.

忽反顧以遊目兮, 將往觀乎四荒。2

Then, the poem recounts his journey through the cosmos, encountering different deities and fantastic creatures one after another at ever more elevated celestial sites, seeking the solace that he so desperately needs. In contrast to the stark landscape in the "Jiu ge" poems, focusing on just one single spot, the "Li sao" gives its readers the whole world. The very idea of a celestial journey itself already presupposes a spatial framework in the poem. Moreover, spatial markers structure its entire narrative throughout, and in the few moments when the poet in flight is not consorting with various deities at different corners of the cosmos, he would pause and look over the vast expanse of space in which he has found himself:

I looked all around over the earth's four quarters,

Circling the heavens till at last I alighted.

I gazed on a jade tower's glittering splendor

And spied the lovely daughter of the Lord of Song.

覽相觀於四極兮, 周流乎天余乃下。望瑤臺之偃塞兮, 見有贱之佚女。 ${ }^{30}$

The examples of "Li sao" and poems in the "Jiu ge" cycle we have just discussed here are typical of the Chuci repertoire as a whole. Representations of space, and the movement of things within it, are structural to all the poems in the Chuci. The narratives of each and every poem always take place ostensibly at a certain place and in space. ${ }^{31}$

But with that said, they are not just disinterested literary cartographies or topographical surveys. The spatial ventures that we see everywhere in the Chuci are

29 Ibid., 18.

30 Ibid., 32.

31 I follow Kümin and Usborne’s suggestion in understanding "point” as a "physical gridreference," "place" as "points where specific constellations of objects and agents constitute socially recognized sites of interaction," and finally, "space" as "fields of perception and maneuver experienced by humans at any point or place." See Beat Kümin and Cornelie Usborne, 'At Home and in the Workplace: A Historical Introduction to the "Spatial Turn",' History \& Theory, 52.3 (2013), 317-318. 
always, without exception, prompted and informed by the affective state of the poet. To illustrate this, let us turn to the opening lines of the poem "Yuan you":

Grieved by the parlous state of this world's ways,

I wanted to float up and roam far away.

But my powers were too weak to give me support:

What could I ride on to bear me upwards?

悲時俗之迫阨兮, 願輕舉而遠遊。質菲薄而無因兮, 焉託乘而上浮。32

The desire to “roam far away" (yuan you 遠遊) was provoked by the poet's unhappiness with the state of the world. His discontent was what prompted this sudden awareness of the space above him. There is a continuity and correlation between his affective interiority and the awareness of an open space beyond his immediate surrounding. It is on the foundation of his unhappiness that space became relevant and meaningful as a possible means of resolution. In these Chu lyrics, the poets do not travel and gaze upon the world for their own pleasure; they do so always to fulfill a lack. In the case of the "Yuan you," after these opening lines, the poet did indeed begin his journey through the cosmos, seeking relief for this unhappiness somehow. Towards the end of the poem, after a fantastic, exhilarating journey through the cosmos, it seems as if he has at last attained happiness:

I wanted to leave for good, to forget about returning:

My mind was exalted with a reckless sense of freedom;

A boundless satisfaction suffused my being:

I wanted to yield to this voluptuous contentment.

欲度世以忘歸兮, 意恣睢 担撟。內欣欣而自美兮, 聊媮娛 自樂。3

No longer feeling aggrieved, he was ready to "leave for good" (or more literally, "to transcend the world" [ $d u$ shi 度世]). But then, he was suddenly plunged back into a great sadness:

Traversing the blue sky, I was wandering freely, When suddenly I glimpsed my old home below me.

My groom was homesick and my own heart downcast;

The trace-horses looked back and would not go forward.

I pictured my dear ones in imagination,

And, with a heavy sigh, I brushed the tears away.

涉青雲 汎濫游兮, 忽臨晲夫舊鄉。僕夫懷余心悲兮, 邊馬顧而不行。思舊故 想像兮, 長太息而掩涕。 ${ }^{34}$

32 Hong Xingzu, Chuci buzhu, 163.

33 Ibid., 171-172.

34 Ibid., 172. 
The poet is caught in an impossible situation here. At the start of the poem, he was unhappy at home, and so he decided to take flight through the cosmos to find relief. When it seemed like he had at last succeeded, he nevertheless felt miserable for remembering that this newfound happiness was attained away from home where he belonged. There is no place in the world where he can be truly happy. Home is where his original unhappiness lies, and by removing himself away from it, whatever momentary sense of relief or even joy that he experiences is bound to be eclipsed by the sadness of being an exile. So, what final resolution might there be for the poet? The conclusion of the poem is ambiguous:

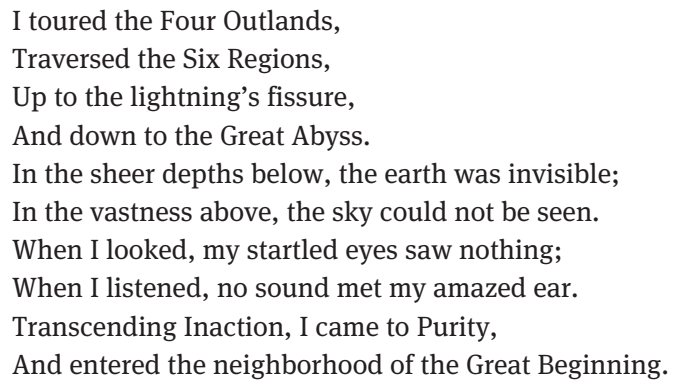

Having journeyed through the entire cosmos - the "Four Outlands" (si huang 四荒) and the "Six Regions" (liu mo 六漠) - he finally attains some measure of peace, a state of "Purity" (zhi qing 至清) away from the foulness in the world that prompted his celestial journey in the first place, by being literally nowhere, a place with no sight and sound that is reminiscent of the primordial state of the world (i.e. the "Great Beginning"). The idea that he can only be at ease by being nowhere means that he is condemned to be terminally displaced in this world; there is literally not a single place for him in the entire cosmos. Agitated by his discontent with the ways of the world where he was, the poet escapes into the vast expanse of the cosmos, only to discover that the only place he truly belongs is nowhere. In the "Yuan you," the literary construction of this most expansive cosmic landscape, in the end, serves to articulate a most radical spatial displacement of an individual.

This idea of displacement, related through an affective landscape, so powerfully and elegantly set forth in the "Yuan you," is in fact quite typical throughout the Chuci corpus. Frustrated by the corrupt state of the world or anxious to

35 Ibid., 174-175. 
acquire something that he does not already have, the poet sets out on a journey in quest of whatever it is that he desperately desires, be it an encounter with a deity, the attainment of immortality, or just an appreciative audience. And in the end, he always fails. This is not a new observation about the Chuci; for instance, long ago, David Hawkes has noted the invariable failures of these quests of the poets, especially in the "Jiu ge" cycle. ${ }^{36}$ What I would add here is that this discontent of the poets always implicates an engagement with space in the Chuci. It is an unhappiness founded on a sense of the displacement of things. In the "Li sao" and "Yuan you," it is the poet himself who is displaced, traversing the whole cosmos in search of a welcoming abode; in some other poems, such as “Huai sha” 懷沙 (“Embracing Sand”), the whole world is in utter disarray:

White is changed to black;

The high cast down and the low made high;

The phoenix languishes in a cage,

While hens and ducks can gambol free.

變白以為黑兮, 倒上以為下。鳳皇在笯兮, 雞䳱翔舞。 ${ }^{37}$

Not only are things out of place, they are precisely where they are not supposed to be. It is a world turned upside down. We can find this motif elsewhere in the literature of the late Warring States and the early empires, but in the Chuci corpus, the focus on this idea of things being out of place is just absolutely relentless. ${ }^{38}$ In one Chu lyric after another, we bear witness to a world where all things have become ruefully unmoored. And for its unhappy denizens, the only possible redemption is to be nowhere, figuratively as it was in "Yuan you" or literally as in the "Yufu" where Qu Yuan saw suicide as the only possible escape. ${ }^{39}$ This poetics of displacement saturates the Chu lyrics. The Chuci is a world of unhappiness in space.

36 Hawkes, The Songs of the South, 49.

37 Hong Xingzu, Chuci buzhu, 143.

38 The poems at the end of the “Fupian” 賦篇 of the Xunzi 荀子(ca. third century BCE) are a great early example; it is also a common motif in the some of the Han dynasty fu 賦 pieces, such as the "Funiao fu” 鵬鳥賦by Jia Yi 賈誼 (200-168 BCE). See David Knechtges, "Riddles as Poetry: The Fu Chapter of the Hsün-tzu," in Wen-lin, ed. Chow Tse Tsung (Madison: University of Wisconsin; Hong Kong: The Chinese University of Hong Kong, 1989), 2.1-32.

39 Hong Xingzu, Chuci buzhu, 143. 


\section{Chuci and the politics of space}

All utterances are inherently dialogic. ${ }^{40}$ What or who then did the Chu lyrics address? Given that the Chuci poems and their lore were the object of much attention under the Han empire, as we discussed earlier, who were their interlocutors and what concerns might have animated this persistent interest in them? With this reading of the Chuci corpus as a poetic language for articulating the idea of displacement, I would suggest that the poems were mobilized as a response to the spatial claims of the early empires. More specifically, it was a reaction to the politicization of space under the Qin and Han empires with their proclamation that they had created a perfectly ordered space. The presumption that a good state is one that creates a well-ordered space, with everything in its right place, has a long history that pre-dates the Qin and the Han, as Mark E. Lewis has demonstrated. ${ }^{41}$ One can find an eloquent expression of this idea, for instance, in the "Yu gong” 禹貢 (“Tributes of Yu") chapter of the Shangshu 尚書 from the fourth or third century BCE. ${ }^{42}$ In it, the legendary Great Yu 禹 was said to have fixed the great floods and remade the world into a welldemarcated, coherent space where all things circulated properly. In the court literature of both the Qin and Han empires, we can find very comparable arguments by the ruling elite about their work in ordering the space of their empires. They stand in sharp contrast to the language and content of the Chuci corpus that we have just discussed and provide, I would argue, an important context for understanding the history - especially the sudden interest - in Chu lyrics at the time.

The rise and the founding of the Qin empire had always been a project in and through spatial expansion and organization. The military conquest of one kingdom after another in the long third century BCE, and subsequently, the remaking of the territories of the old kingdoms (guo 國) into the thirty-six commanderies (jun 郡)

40 M. M. Bakhtin, The Dialogic Imagination: Four Essays, ed. by Michael Holquist, trans. by Michael Holquist and Caryl Emerson, University of Texas Press Slavic Series; No. 1 (Austin: University of Texas Press, 2004), esp. 259-422.

41 Mark Edward Lewis, The Construction of Space in Early China (Albany: State University of New York Press, 2006).

42 Qu Wanli 屈萬里, Shangshu ji shi 尚書集釋 (Taipei: Jinglian chuban shiye gongsi, 1983), 42-72. See the discussion in Robin McNeal, 'Spatial Models of the State in Early Chinese Texts: Tribute Networks and the Articulation of Power and Authority in Shangshu "Yu Gong" and Yizhoushu "Wang Hui"', in Origins of Chinese Political Philosophy: Studies in the Composition and Thought of the Shangshu (Classic of Documents), ed. by Martin Kern and Dirk Meyer, Studies in the History of Chinese Texts (Leiden; Boston: Brill, 2017), 475-95. 
were some of the key measures that it took to refashion the empire's landscape for political ends. After the founding of the empire, its initiatives to unify the writing script, measurement units, and axle lengths also point towards its desire for a homogeneous, coherent space that would allow for an unobstructed dissemination of its imperial commands. ${ }^{43}$ Qin's political authority was, at least in part, constituted by a deliberate "making and remaking of landscapes." 44

For evidence of how the Qin imagined this new space of the empire, let us turn to its court literature. ${ }^{45}$ Specifically, let us look at the series of stele inscriptions commissioned by the First Emperor of the Qin (Qin shi huangdi 秦始皇帝, r. 221-210 BCE). ${ }^{46}$ For example, the one erected on Mount Zhifu 之罡, from the year 218 BCE, begins as follows:

In the twenty-ninth year the August Emperor set forth in spring, inspecting and visiting the distant regions. Advancing to the brink of the sea, he ascended Mt. Zhifu, gazing down at the morning sun.

維二十九年, 皇帝春游, 覽省遠方。逮于海隅, 遂登之罧, 昭臨朝陽。 ${ }^{47}$

Here, the Qin emperor ascends to an elevated spot, overlooking the vast landscape that opens up before his eyes, not unlike the Chuci poets in "Li sao" and "Yuan you" who surveyed the cosmos from high above, as we have seen earlier. And what does he see? The inscription continues with the following marvelous description:

43 Sima Qian, Shiji, 6.239-240. See also Charles Sanft, Communication and Cooperation in Early Imperial China: Publicizing the Qin Dynasty (Albany: State University of New York Press, 2014), esp. 57-76.

44 Adam T. Smith, The Political Landscape, 5.

45 I refer to Jack Chen's definition of the "court" as a "spatial figuration of the various relationships among the sovereign (emperor, king, or prince), ministers, officials, and other court personnel," and therefore, physically, it can be "wherever the ruler and his officials were, whether in the capital, en route from one palace to another, or on the frontiers." Jack Chen, 'Sites I', in The Oxford Handbook of Classical Chinese Literature (1000 BCE-900 CE), ed. by Wiebke Denecke, Wai-Yee Li, and Xiaofei Tian (New York: Oxford University Press, 2017), 426. See also Luke Habberstad, Forming the Early Chinese Court: Rituals, Spaces, Roles, The Modern Language Initiative (Seattle: University of Washington Press, 2017).

46 On the reliability of the stele inscriptions as historical sources for the Qin empire, see Martin Kern, The Stele Inscriptions of Ch'in Shih-huang: Text and Ritual in Early Chinese Imperial Representation (New Haven: American Oriental Society, 2000).

47 Sima Qian, Shiji, 6.250. Unless otherwise noted, translations from Sima Qian's Shiji are taken from Burton Watson, Records of the Grand Historian: Qin Dynasty (Hong Kong and New York: Columbia U.P., 1993) and Records of the Grand Historian: Han Dynasty II (Hong Kong and New York: Columbia U.P., 1993), with minor modifications. 
The vista was vast and beautiful, and the ministers in his retinue all pondered, searching out the source of his supreme enlightenment. When the sage's laws were first promulgated, they brought purity and order within the borders and punished the unruly and powerful beyond them. His warlike might was brandished on wide, shaking the four corners of the land; he took captive the kings of the Six States. . . . Office holders have the honor due them, each understands his duties, so all proceeds without ill-feeling or doubt. The commoners have undergone transformation, near and far share a single rule, an achievement far surpassing antiquity.

觀望廣麗, 從臣咸念, 原道至明。聖法初興, 清理疆內, 外誅暴彊。武威旁暢, 振動四極, 禽滅 六王。。。職臣遵分, 各知所行, 事無嫌疑。黔首改化, 遠邇同度, 臨古絕尤 ${ }^{48}$

In contrast to the desolate landscape depicted in the Chuci poems, scattered with unwelcoming deities among things out of place, what the Qin emperor saw was the exact opposite: a perfectly ordered world, where all his ministers know exactly where they stand and have none of the sort of "ill-feeling" and “doubt” (xianyi 嫌疑) that are a constant source of anxiety for the forlorn, troubled poets in the Chuci. ${ }^{49}$

This vision of a grand, perfect order is ubiquitous throughout the Qin stele inscriptions. Here is another example from the Mount Langya inscription:

Within the six directions, the domain of the August Emperor, west to the flowing sands, south all the way to Beihu, east to the eastern sea, north beyond Daxia, wherever human tracks may reach, there are none who are not his subjects. In merit he tops the Five Emperors, his bounty reaching oxen and horses, none untouched by the ruler's virtue, each at rest in his home.

六合之內, 皇帝之土。西涉流沙, 南盡北戶。東有東海, 北過大夏。人迹所至, 無不臣者。 功蓋五帝, 澤及牛馬。莫不受德, 各安其宇。 ${ }^{50}$

This perfectly ordered cosmos are all the emperor's domain; everything is exactly where they belong and all can be “at rest in his home” (ge an qi yu 各安其宇). Once again, we see a world that is diametrically opposite to the world depicted in the Chuci, where all things are displaced, and home is where one wants to be but cannot remain. The spatial visions in these two bodies of texts - the Chuci and the Qin stele inscriptions - are the inversions of one another. While the Qin stele inscriptions speak of a universal order with proper placements of all things, the Chuci imagines an inescapable chaos where everything is continually out of place and nothing can ever be at rest anywhere.

48 Sima Qian, Shiji, 6.250.

49 Hong Xingzu, Chuci buzhu, 149.

50 Sima Qian, Shiji, 6.245. 
These imperial claims about state spatial organization did not perish with the short-lived Qin empire; they were soon to be inherited by its successor the Han, especially under the reign of Emperor $\mathrm{Wu}$, a period that saw the reconstitution of much of the centralized bureaucratic order first introduced by the Qin as well as a notable surge of interest in the Chu lyrics tradition, as we have noted earlier. In the “Hequ shu” 河渠書 (“Treatise on the Yellow River and Canals") of the Shiji, for instance, Sima Qian details the many efforts by Emperor $\mathrm{Wu}$ to position the waterways within the empire, at times even overtly following Great Yu's legendary plan as described in the "Yu gong," to achieve a spatial layout that will lead to a good order. ${ }^{51}$ In the "Fengshan shu” 封禪書 (“The Treatise on the Feng and Shan Sacrifices”), also from the Shiji, we see Emperor Wu, following the example of the First Emperor of Qin, imagining his dominion as having extended to all things in the cosmos. ${ }^{52}$ In the “Tian guan shu” 天官書 ("The Treatise on Celestial Offices"), likewise from the Shiji, we see reiterations of the idea that the creation of an imperial order necessarily involves an ordering of the cosmic space and an alignment of all the heavenly entities within it. ${ }^{53}$ Together, these texts suggest a degree of continuity between the Qin of the First Emperor and the Han of Emperor Wu in their contention about the spatial order of the empires.

For a more dramatic illustration of the Han imperial spatial imagination under Emperor Wu's reign, we can hardly do better than to have a look at the "Da ren fu” 大人賦 (“Rhapsody on the Great One”) by Sima Xiangru 司馬相如 (179-117 BCE). Written for Emperor Wu's audience, it recounts the cosmic journey of the "Great One," presumably a stand-in for the emperor himself given the context of the composition..$^{54}$ On first reading, it is reminiscent of the poems of cosmic journey in the Chuci; it even shares a few identical passages with the "Yuan you" in addition to their already very similar vocabulary and prosody. Both poems begin with this identical passage: “Grieved by the parlous state of this world's ways, I wanted to float up and away with it” (悲時俗之迫阨兮, 願輕舉而遠遊). ${ }^{55}$ In the "Yuan you," as we have discussed earlier, this initial unhappiness was never fully expelled as the poet journeys through the cosmos. In contrast, whatever grief that

\footnotetext{
51 Ibid, 29.1413.
}

52 Ibid, 28.1355-1404, 6.235-263. See also the discussion in Michael Puett, To Become a God: Cosmology, Sacrifice, and Self-Divinization in Early China (Cambridge: Harvard U.P., 2002), 287-316.

53 Sima Qian, Shiji, 27.1346-1347.

54 Ibid, 117.3062.

55 Ibid, 117.3056; and Hong Xingzu, Chuci buzhu, 163. 
the Great One might have experienced at the start of the "Da ren fu," it soon dissipates as he takes a triumphant and exhilarating journey across the universe. Traveling confidently from one celestial spot to another, he snatches stars and rainbows for his own adornments, and he commands divine figures and fantastic creatures throughout the cosmic realm to help him "survey the eight directions and the four outer wastes, ford the Nine Rivers and pass over the Five Streams" (徧覽八紘而觀四荒兮, 堨渡九江而越五河). ${ }^{56}$ It is an orderly cosmos under the dominion of the emperor, with all things are exactly where they are supposed to be. Towards the end, after the climactic encounter with the Queen Mother of the West (Xiwangmu 西王母), the poem concludes as follows:

Beneath him in the vastness, the earth has disappeared;
Above his head the heavens vanish in endless space.
Gazing about, his eyes swim and grow sightless;
His ears are deafened and discern no sound.
Riding upon the Void, he mounts on high
Above the world of men, companionless, to dwell alone.

下崢嵓而無地兮, 上骞廓而無天。視眩眠而無見兮, 聽惝恍而無聞。乘虛無而上假兮, 超無 友而獨存。 ${ }^{57}$

This is nearly identical to the ending of "Yuan you," but nevertheless, the contexts of the two are vastly different. In the "Yuan you," the dejected poet ended up being nowhere in a world where he felt perpetually displaced. In the "Da ren fu," however, after a jubilant, commanding tour of the cosmos, the detached state of the Great One at the end connotes not a withdrawal from the world but its subjugation and transcendence. His solitude further correlates with the singularity of this attainment. No wonder that Emperor Wu, upon hearing the performance of the "Da ren fu," was "overcome with delight, declaring that it made him feel as though he were already whirling away over the clouds and filled him with a longing to wander about the earth and the heavens" (天子 大說, 飄飄有淩雲之氣, 似游天地之閒意). ${ }^{58}$ The “Da ren fu" celebrates a world

56 Ibid, 117.3060 .

57 Ibid, 117.3062.

58 Ibid, 117.3063. Sima Xiangru's fu poems, of course, are not just simple celebration of the accomplishments of Emperor $\mathrm{Wu}$, but they can also be read as subtle critique and remonstrance. See Wai-yee Li, 'Riddles, Concealment, and Rhetoric in Early China', in Facing the Monarch: Modes of Advice in the Early Chinese Court, ed. by Garret P. S. Olberding (Cambridge, Mass.; London: Harvard University Asia Center, distributed by Harvard University Press, 2013), 100-132; Fusheng Wu, "Han Epideictic Rhapsody: A Product and Critique of Imperial Patronage," Monumenta Serica, 55 (2007), 23-59. 
properly ordered, and thus brought under control by its singular ruler, while the "Yuan you" bemoans the never-ending, all-encompassing chaos where the only hope for salvation is oblivion.

So, what are we to make of this dissonance between the spatial representations in the Han court literature and the Chuci? Recall that in our overview of the Chuci under the early empires, we noted that there was this consistent and persistent interest in the Chu lyrics tradition and its lore throughout the period of the Han empire. Over the four centuries of the Han dynasty, we saw the compositions of new imitative pieces, elaboration of its founding legends (i.e., the story of $\mathrm{Qu}$ Yuan), and the compilation of its canonical pieces (i.e. Wang Yi's Chuci zhangju). On one hand, we have a confident rhetoric of good spatial order in the court literature of the Qin and Han empires; on the other hand, there is also this attentiveness to a poetic language of displacement among the political elite of the empires at the same time. With this dissonance in mind, I would argue that this surge of interest in Chu lyrics under the Han was largely prompted by these radical spatial claims of the early empires, first made by the Qin and then the Han. The Chu lyrics tradition invited attention from Han politicians who recognized it as an intellectual and literary resource for reflecting upon or even critiquing the empire's claim of having fashioned a perfectly well-ordered space. In a world where everything is said to be already in its right place, Chu lyrics provides a refined, eloquent language that allows one to imagine otherwise. As a poetic language designed for articulating displacement, it became all the more resonant in a world that preemptively banished such spatial disorder as a thing of the past, an impossibility in the present.

The Chu lyrics afforded not just mere literary pleasure for its Han readers, but a critical resource for contemplating and interrogating the grandiose spatial claims of the new empires. Not surprisingly, therefore, Jia Yi turned to elaborating on the legend of Qu Yuan in his "Diao Qu Yuan fu" precisely at the moment when he was exiled from the Han capital to the periphery of this supposedly perfect order of the empire, or Sima Qian invoked Qu Yuan in his "Bao Ren An shu” 報任安書 (“Letter in Reply to Ren An”) as an authorial model in his justification for the compilation of the Shiji after he was disgraced at the court of Emperor $\mathrm{Wu} .{ }^{59}$ Having been displaced from what they thought were their rightful positions in a supposedly perfectly ordered world, these Han politicians turned to the past and seized upon the tradition of Chu lyrics to imagine and articulate a

59 Ban Gu, Hanshu, 62.2725-2736, esp. 2735. See Wai-yee Li, “The Letter to Ren An and Authorship in the Chinese Tradition,” in The Letter to Ren An \& Sima Qian's Legacy, ed. by Stephen W. Durrant and others (Seattle: University of Washington Press, 2016), 96-123. 
world gone awry. In these moments of danger, to borrow a phrase from Walter Benjamin, these Han politicians seized hold of the memory of Chu kingdom and its lyrical tradition to try to make sense of it all. ${ }^{60}$

Put differently, the Chuci phenomenon in the early imperial period can be understood as a consequence of the radical politicization of space under the rise of empires in early China. The Qin and Han empires were founded, in part, on their work in re-ordering the spatial relations between all things in their expansive dominions. The ideological fantasy, as we have seen in the example of the Qin stele inscriptions, is that the new spatial order that they have fashioned was perfect or even natural, in the sense that all things are now restored to where they rightfully belong in this new world that they have created. The good order that the empires have so painstakingly achieved has conferred upon the world a second nature to which all should happily submit. ${ }^{61}$ In such a political landscape, one can imagine the great pleasure afforded by the Chu lyrics for its fabulation of a world displaced. Its elegant yet melancholic language allows for the articulation of dystopia in a purportedly utopian realm. In a more radical context, we can also see how the Chu lyrics tradition offered the political elite a language of political subversion. It was a well-wrought language that can be used to articulate an alternative description of this new space of the empires one filled with things that were displaced, unmoored, or perverted. And of course, like all politically subversive languages, it was susceptible to appropriation by the state. The "Da ren fu" by Sima Xiangru was perhaps such a case; superficially, at least, it seemed to have proclaimed rather than interrogated this supposedly well-ordered space of the Han empire.

To create a new state is to create a new space, as I said at the very beginning. Not only did the Qin and the Han empires make and remake the spaces of their dominion, but they also proclaimed a lasting perfection for the new landscape that they had fashioned. ${ }^{62}$ The Qin empire fell in relatively short order,

60 Walter Benjamin, "On the Concept of History," in Selected Writings, ed. by Howard Eiland and Michael William Jennings, trans. by E. F. N. Jephcott, 4 vols (Cambridge, Mass.: Belknap Press, 1996), iv, 391.

61 This argument for the possibility of political innovations to align humanity with the natural order has a long genealogy that can be traced back to the ideas preserves in the Xunzi. See the discussion in Michael J. Puett, The Ambivalence of Creation: Debates Concerning Innovation and Artifice in Early China (Stanford: Stanford U.P., 2002), 64-73.

62 One may also relate this self-image of the Qin empire to its conceit that it had brought about the "end of history," a perfect form of government that will last indefinitely into the future. See Yuri Pines, 'From Historical Evolution to the End of History: Past, Present and Future from Shang Yang to the First Emperor', in Dao Companion to the Philosophy of Han Fei, ed. by Paul R. Goldin (Dordrecht: Springer Netherlands, 2013), 25-46. 
but the Han did manage to sustain its imperial rule for centuries. The rise of the Qin and Han empires was, as this study of the Chuci would suggest, attended by the emergence of a contentious imagination of the spaces of empires, within which we find a whole range of positions between seeing the new imperial regimes as a sublime utopia of order or a ruinous dystopia of displacement, all of which could and were effectively articulated by way of the language of the Chu lyrics. It was for this reason, in part, that the Chuci was elaborated as a discursive site over the course of the Han empire.

The political transition from the old aristocratic kingdoms of the late Warring States to the new bureaucratic empires of the Qin and the Han was achieved, in part, through a remaking of landscape. In the process, space was inevitably politicized. Political ideals were articulated through specific spatial orders, and political authority rested on the creation and perpetuation of proper spatial relations. In this context, the tradition of Chu lyrics, with its refined poetics of displacement, emerged as an eloquent resource for articulating and reflecting on this new contentious imagination of the spaces of empires. The persistence and deepening of this interest in the lyrics of $\mathrm{Chu}$, which extends to other legends and personalities such as Qu Yuan and Song Yu, from the first decades of the Han to the time of Wang Yi's Chuci zhangju in the last century of the empire, is perhaps indicative of the endurance of this contentious question of space throughout the early imperial period. Juxtaposing the Chuci and the Qin-Han court literature gave us a glimpse into this politics of space under the early empires at perhaps the most rarefied, abstract level. Much work remains to be done to flesh out the history of the production of space under the rise of empires in early China.

\section{References}

Bakhtin, M. M., The Dialogic Imagination: Four Essays, ed. by Michael Holquist, trans. by Michael Holquist and Caryl Emerson, University of Texas Press Slavic Series; No. 1 (Austin: University of Texas Press, 2004)

Ban, Gu 班固, Hanshu 漢書, 12 vols (Beijing: Zhonghua shuju, 1975)

Benjamin, Walter, 'On the Concept of History', in Selected Writings, ed. by Howard Eiland and Michael William Jennings, trans. by E. F. N. Jephcott, 4 vols (Cambridge, Mass.: Belknap Press, 1996), iv, 389-400

Blakeley, Barry B., 'The Geography of Chu', in Defining Chu: Image and Reality in Ancient China, ed. by Constance A. Cook and John S. Major (Honolulu: University of Hawai'i Press, 1999), 9-20

Chan, Ping-Leung, 'The Sacred and the Profane: A Study of "Chiu Ko"', Tamkang Review, 15 (1984), 451. 
Chang, K. C., Art, Myth, and Ritual: The Path to Political Authority in Ancient China (Cambridge, Mass.; London: Harvard University Press, 1983)

Denecke, Wiebke, Wai-Yee Li, and Xiaofei Tian, eds., The Oxford Handbook of Classical Chinese Literature (1000 BCE-900 CE) (New York: Oxford University Press, 2017)

Doyle, Michael W., Empires (Ithaca, N.Y.: Cornell University Press, 1986)

Fan, Ye 范曄, Hou Hanshu 後漢書 (Beijing: Zhonghua shuju, 1965)

Fujino, Iwatomo 藤野岩友, Fukei bungakuron 巫系文学論 (Tōkyō: Daigaku Shobō, 26)

Habberstad, Luke, Forming the Early Chinese Court: Rituals, Spaces, Roles, The Modern Language Initiative (Seattle: University of Washington Press, 2017)

Hardt, Michael, and Antonio Negri, Empire (Cambridge, Mass.: Harvard University Press, 2000)

Hawkes, David, 'Ch'u Tz'u', in Early Chinese Texts: A Bibliographical Guide, ed. by Michael Loewe, Early China Special Monograph Series, no. 2 (Berkeley, Calif.: Society for the Study of Early China, Institute of East Asian Studies, University of California, Berkeley, 1993), 48-55

Hawkes, David, trans., The Songs of the South: An Ancient Chinese Anthology of Poems by Qu Yuan and Other Poets, Penguin Classics (Harmondsworth, Middlesex, England; New York, N.Y., U.S.A: Penguin Books, 1985)

He, Tianxing 何天行, Chuci zuo yu Han dai kao 楚辭作於漢代考, Jin dai ming jia san yi xue shu zhu zuo cong kan. Wen xue (Taiyuan: Shanxi renmin chubanshe, 2014)

Hong, Xingzu 洪興祖, Chuci bu zhu 楚辭補注 (Beijing: Zhonghua shuju, 1983)

Hu, Shi 胡適, ‘Du Chuci 讀楚辭’, in Hu Shi Wencun 胡適文存 (1989: Shanghai, Shanghai shudian), ii, $139-48$

Huang, Bilian 黄碧璉, Qu Yuan yu Chu wenhua yanjiu 屈原與楚文化研究 (Taipei: Wenjin chubanshe, 87)

Hunter, Michael, 'The “Yiwen Zhi” 藝文志 (Treatise on Arts and Letters) Bibliography in Its Own Context', Journal of the American Oriental Society, 138.4 (2018), 763-780.

Ing, Michael D. K., The Vulnerability of Integrity in Early Confucian Thought (New York, NY: Oxford University Press, 2017)

Jiang, Tianshu 蔣天樞, ‘Hou Hanshu Wang Yi zhuan kaoshi 後漢書王逸傳考釋’, in Chuci lunwen ji 楚辭論文集 (Xi'an: Shanxi renmin chubanshe, 1982), 195-212

Kern, Martin, The Stele Inscriptions of Ch'in Shih-Huang: Text and Ritual in Early Chinese Imperial Representation, American Oriental Series; v. 85 (New Haven, Conn.: American Oriental Society, 2000)

Kern, Martin, 'The Verses of Chu', in The Cambridge History of Chinese Literature, ed. by Kangi Sun Chang and Stephen Owen, 2 vols (Cambridge, UK; New York: Cambridge University Press, 2010), i, 76-85

Knechtges, David, 'Riddles as Poetry: The "Fu” Chapter of the Hsun-Tzu', in Wen-Lin: Studies in the Chinese Humanities, ed. by Tsê-Tsung Chow (Madison: University of Wisconsin Press, 1989), ii, 1-31

Knechtges, David R., and Taiping Chang, eds., Ancient and Early Medieval Chinese Literature: A Reference Guide Part One (Leiden: Brill, 2010)

Kominami, Ichirō 小南一郎, Soji to sono chūshakushatachi 楚辭とその注釈者たち (Kyōto: Hōyū Shoten, 2003)

Kümin, Beat, and Cornelie Usborne, 'At Home and in the Workplace: A Historical Introduction to the "Spatial Turn"', History \& Theory, 52 (2013), 305-318 
Li, Wai-yee, 'Riddles, Concealment, and Rhetoric in Early China', in Facing the Monarch: Modes of Advice in the Early Chinese Court, ed. by Garret P. S. Olberding (Cambridge, Mass.; London: Harvard University Asia Center, distributed by Harvard University Press, 2013), 100-132

$\mathrm{Li}$, Wai-yee, 'The Letter to Ren An and Authorship in the Chinese Tradition', in The Letter to Ren An \& Sima Qian's Legacy, ed. by Stephen W. Durrant, Li, Wai-yee, Michael Nylan, and Hans van Ess (Seattle: University of Washington Press, 2016), 96-123

Li, Longxian 李隆獻, “Wenxuan Song Yu “Dui Chu Wang Wen” Jianzheng Ji Xianggauan de Liangge Wenti” 《文選》宋玉「對楚王問」箋證及相關的兩個問題’, Taida Zhongwen Xuebao 臺大中文學報, 6 (1994), 171-208

Lu, Kanru 陸㑆如, ‘Han ren lun Chuci 漢人論楚辭’, in Lu Kanru gudian wenxue lunwen 陸㑆如 古典文學論文集 (Shanghai: Shanghai guji chubanshe, 1987), 371-401

Maier, Charles S., Among Empires: American Ascendancy and Its Predecessors (Cambridge, MA: Harvard University Press, 2006)

Pines, Yuri, 'From Historical Evolution to the End of History: Past, Present and Future from Shang Yang to the First Emperor', in Dao Companion to the Philosophy of Han Fei, ed. by Paul R. Goldin (Dordrecht: Springer Netherlands, 2013), 25-46

Puett, Michael J., The Ambivalence of Creation: Debates Concerning Innovation and Artifice in Early China (Stanford, Calif: Stanford University Press, 2001)

Puett, Michael J., To Become a God: Cosmology, Sacrifice, and Self-Divinization in Early China, Harvard-Yenching Institute Monographs Series, 57 (Cambridge, Mass.: Harvard University Press, 2004)

Qu, Wanli 屈萬里, Shang shu ji shi 尚書集釋, Qu, Wanli. Works. 1983; 4. Y (Taipei: Lianjing chuban shiye gongsi, 72)

Sanft, Charles, Communication and Cooperation in Early Imperial China: Publicizing the Qin Dynasty, SUNY Series in Chinese Philosophy and Culture (Albany: State University of New York Press, 2014)

Schimmelpfennig, Michael, 'The Quest for a Classic: Wang Yi and the Exegetical Prehistory of His Commentary to the Songs of Chu', Early China, 29 (2004), 111-162

Schneider, Laurence A., A Madman of Ch'u: The Chinese Myth of Loyalty and Dissent (Berkeley: University of California Press, 1980)

Shi, Wenying 石文英, 'Liang Han de Li Sao Zenglun Ji Qi Yanxu 兩漢的《離騷》爭論及其延續, Wen Shi Zhe 文史哲, 2 (1988), 70-75

Sima, Qian 司馬遷, Shiji 史記, 10 vols. (Beijing: Zhonghua shuju, 1959)

Smith, Adam T., The Political Landscape: Constellations of Authority in Early Complex Polities (Berkeley: University of California Press, 2003)

Sukhu, Gopal, 'Monkeys, Shamans, Emperors, and Poets: The Chuci and Images of Chu during the Han Dynasty', in Defining Chu: Image and Reality in Ancient China, ed. by Constance A. Cook and John S. Major (Honolulu: University of Hawai'i Press, 1999), 145-65

Sukhu, Gopal, The Shaman and the Heresiarch: A New Interpretation of the Li Sao, SUNY Series in Chinese Philosophy and Culture (Albany: State University of New York Press, 2012)

Sukhu, Gopal, The Songs of Chu: An Ancient Anthology of Works by Qu Yuan and Others, Translations from the Asian Classics (New York: Columbia University Press, 2017)

Swartz, Wendy, 'Naturalness in Xie Lingyun's Poetic Works', Harvard Journal of Asiatic Studies, 70 (2010), 355-86 
Waley, Arthur, The Nine Songs; a Study of Shamanism in Ancient China (London: Allen and Unwin, 1955)

Wang, Qizhou 王齊洲, ‘Wang Yi He Chuci Zhangju 王逸和《楚辞章句》', Wenxue Yichan 文學 遺產, 1995, 23-30

Watson, Burton, Early Chinese Literature (New York: Columbia University Press, 1962)

Watson, Burton, Records of the Grand Historian: Han Dynasty II, Records of Civilization, Sources and Studies, no. 65, Rev. ed (Hong Kong; New York: Columbia University Press, 1993)

Watson, Burton, Records of the Grand Historian: Qin Dynasty (Hong Kong; New York: Research Centre for Translation, Chinese University of Hong Kong; Columbia University Press, 1993)

Westbrook, Francis A., 'Landscape Transformation in the Poetry of Hsieh Ling-Yün', Journal of the American Oriental Society, 100 (1980), 237-254

Wu, Fusheng, 'Han Epideictic Rhapsody: A Product and Critique of Imperial Patronage', Monumenta Serica, 55 (2007), 23-59

Yao, Zhenzong 姚振宗, Qi lüe bie lu yi wen; Qi lüe yi wen 七略別錄佚文; 七略佚文 (Shanghai: Shanghai guji chubanshe, 2008).

You, Guo’en 游國恩, ‘Chuci de qiuyuan 楚辭的起源', in You Guo'en Chuci lunzhu ji 游國恩楚辭 論著集, 4 vols (Beijing: Zhonghua shuju, 2008), iv, 114-26

You, Guo’en 游國恩, ‘Chuci gailun 楚辭概論’, in You Guo'en Chuci lunzhu ji 游國恩楚辭論著集, 4 vols (Beijing: Zhonghua shuju, 2008), iii, 1-212

You, Guo'en 游國恩, ‘Qu Yuan 屈原', in You Guo'en Chuci lunzhu ji 游國恩楚辭論著集, 4 vols (Beijing: Zhonghua shuju, 2008), iii, 406-548

Zhao, Hui 趙輝, Chuci wenhua beijing yanjiu 楚辭文化背景研究, Chu xue wen ku (Wuhan: Hubei jiaoyu chubanshe, 1995)

Zhao, Kuifu 趙逵夫, Qu Yuan yu ta di shidai 屈原與他的時代 (Beijing: Renmin wenxue chubanshe, 1996)

Zhou, Weifeng 周莘風, Chuci fashengxue yanjiu 楚辭發生學研究 (Guilin: Guangxi shifan daxue chubanshe, 2008) 
